\title{
16. INITIAL REPORT ON DOWNHOLE TEMPERATURE AND SHIPBOARD THERMAL CONDUCTIVITY MEASUREMENTS, LEG 19, DEEP SEA DRILLING PROJECT
}

\author{
Al Erickson, Woods Hole Oceanographic Institution, Woods Hole, Massachusetts
}

\section{INTRODUCTION}

Downhole temperatures were measured at Sites 183, 184, and 185 in the Gulf of Alaska and Bering Sea (Table 1) during Leg 19 of the JOIDES Deep Sea Drilling Project using a self-contained, digital temperature recorder developed at the Woods Hole Oceanographic Institution. All temperature data were collected using downhole hardware and techniques which are compatible with normal coring and drilling practices aboard the D/V Glomar Challenger. Temperature data were obtained over a wide range of depths between 16 and 691 meters beneath the sea floor and in sediment types ranging from very soft mud to hard, lithified rock. The temperature data show excellent time correlation with known drilling events and downhole conditions and, in several instances, are believed to be useful for calculation of in situ sediment temperatures.

TABLE 1

Leg 19 Site Locations and Water Depths

\begin{tabular}{lccc}
\hline Site & Latitude & Longitude & $\begin{array}{c}\text { Water Depth } \\
(\mathrm{m})\end{array}$ \\
\hline 183 & $52^{\circ} 34.30^{\prime} \mathrm{N}$ & $161^{\circ} 12.33^{\prime} \mathrm{W}$ & 4708 \\
184 & $53^{\circ} 42.64^{\prime} \mathrm{N}$ & $170^{\circ} 55.39^{\prime} \mathrm{W}$ & 1910 \\
185 & $54^{\circ} 25.73^{\prime} \mathrm{N}$ & $169^{\circ} 14.59^{\prime} \mathrm{W}$ & 2110 \\
188 & $53^{\circ} 45.21^{\prime} \mathrm{N}$ & $178^{\circ} 39.56^{\prime} \mathrm{E}$ & 2649 \\
190 & $55^{\circ} 33.55^{\prime} \mathrm{N}$ & $171^{\circ} 38.42^{\prime} \mathrm{E}$ & 3875 \\
$191 \mathrm{~A}$ & $56^{\circ} 56.70^{\prime} \mathrm{N}$ & $168^{\circ} 10.72^{\prime} \mathrm{E}$ & 3860 \\
192 & $53^{\circ} 00.57^{\prime} \mathrm{N}$ & $164^{\circ} 42.81^{\prime} \mathrm{E}$ & 3014 \\
193 & $45^{\circ} 48.20^{\prime} \mathrm{N}$ & $155^{\circ} 52.27^{\prime} \mathrm{E}$ & 4811 \\
\hline
\end{tabular}

Over 100 thermal conductivity measurements were made on cores from Leg 19 drill sites. The conductivity data at some sites show good correlation with bulk density, porosity, and natural gamma-ray activity. At other sites, with more homogeneous sediments, the correlation is either unclear or weak, probably due to the effect of mechanical disturbances caused by coring, which produce variations in physical properties as large or larger than those ocurring naturally. High thermal conductivity values (2.6 to 3.2 $\mathrm{mcal} / \mathrm{cm} \mathrm{sec}{ }^{\circ} \mathrm{C}$ ) were common for coarse-grained, terrigenous material and for very clay-rich sediments. Lower thermal conductivity values, in the range 1.9 to 2.1 $\mathrm{mcal} / \mathrm{cm} \mathrm{sec}{ }^{\circ} \mathrm{C}$, are characteristic of nearly pure diatom oozes. The thermal conductivity of diatom-rich pelagic sediments increases as the proportion of clay increases. As additional thermal conductivity, lithologic, and physical property data become available, it is likely that these data will define empirical relationships between these properties which can be used reliably to predict thermal conductivity in strata whose conductivity has not been measured.

\section{DOWNHOLE TEMPERATURE DATA}

\section{General Description of Equipment}

The essential features of the downhole system are shown in Figure 1. They are 1) the downhole temperature recorder housed in a pressure case 2-3/8 inches in diameter and 32 inches long, 2) the thermistor probe and $3 / 4$ inch diameter extender, and 3) a release latch and slider on the extender designed to release the probe-recorder assembly after bottom penetration of the probe so that the entire assembly may slide up inside the inner core barrel after measurement of the in situ sediment temperature. The downhole instrument records the ambient temperature of the sediment 20 to $100 \mathrm{~cm}$ beneath the level of thermal disturbance caused by drilling. The temperature data are recorded on a magnetic drum every 8 seconds in the form of a sixteen-bit serial binary word. The resolution of the records is better than $0.01^{\circ} \mathrm{C}$. The instrument was electrically reliable and (under normal use) mechanically rugged. Some mechanical problems (principally bent interconnecting pins between some of the printed circuit boards) were encountered. Data readout and battery charging were generally accomplished quickly and effectively through a bulkhead passthrough without opening the pressure case. In conclusion, only minor modifications are necessary on the three downhole temperature recorders to make them acceptable for routine use.

The 3/4-inch-diameter extenders and 3/8-inch-diameter thermistor probes were adequate. Slightly smaller probes with a shorter thermal time constant would be desirable for use in holes where sediment strength and the use of a float valve above the bit are not limiting factors. In seventeen trials, only one extender (later straightened and reused) and two thermistor probes were bent. Meaningful temperature data were obtained on eight lowerings. There was no leakage or disruption of the measurement due to flooding of the probes.

The latch and slider system did not function effectively at all times on Leg 19. The major problem was premature release of the instrument up the core barrel, preventing effective penetration of the sediment. The latch system is presently being modified.

\section{Presentation of Data}

The ability of the downhole temperature recording system to measure temperatures in the drill string and in the sediment is demonstrated in Figures 2 through 8 . These figures show downhole temperatures plotted against time elapsed since the start of data acquisition. Interpretations of the events associated with these plots have been noted 


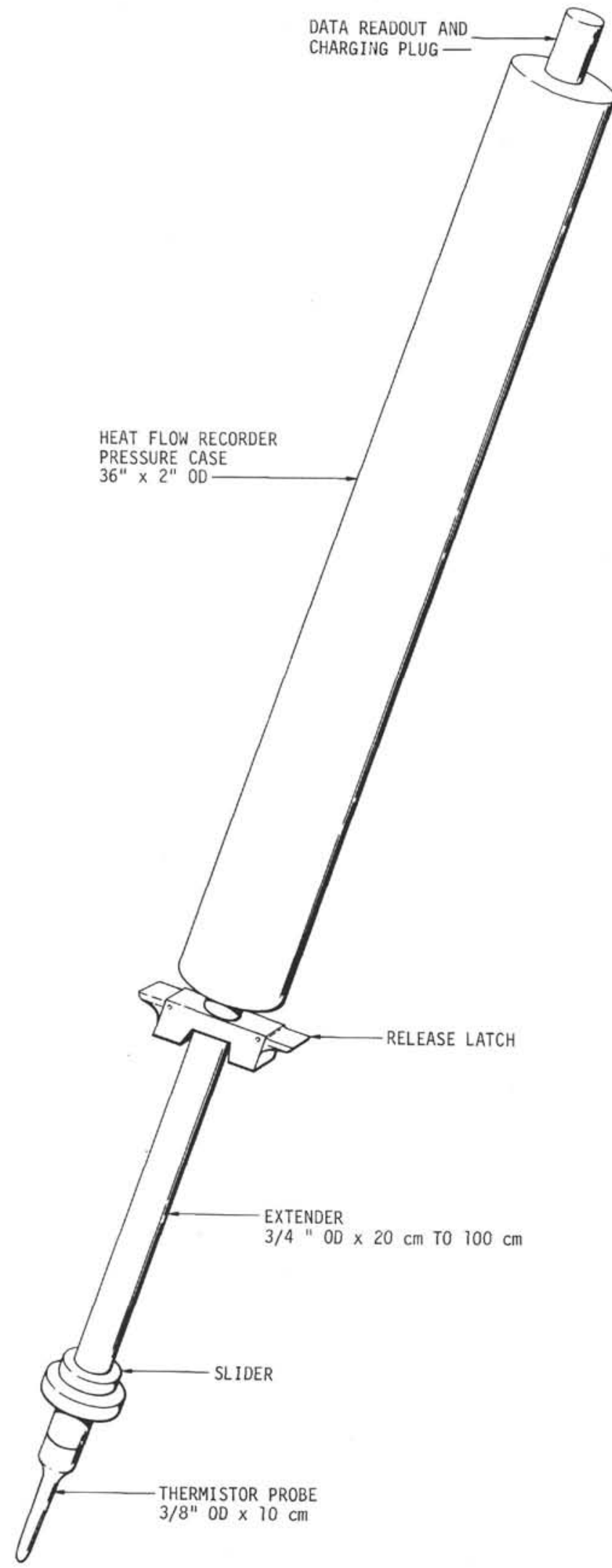

Figure 1. Downhole heat-flow apparatus.

on the figures to facilitate understanding the temperaturetime graphs. These captions are based upon the correlation between a detailed operations log kept during each downhole temperature determination and the temperature data.

Thermal disturbances caused by slumping of material from the sides into the bottom of the hole, circulation of drilling fluid before or during the temperature measurement, or failure of the probe to penetrate the undrilled sediment due to premature release of the probe up inside the drill string should all produce anomalously (and variably) low in situ sediment temperatures. Heat is produced at the bottom of the drill hole through the conversion of mechanical to thermal energy (particularly during coring); however, almost all of this heat is carried away from the undrilled sediment by circulation of the drilling fluid and cuttings. The downhole temperature measurements made on this leg provide a basis for identifying and separating geophysically significant downhole temperature data from anomalous data affected by mechanical or thermal perturbations. The thermal gradient, $d T / d Z$, has been calculated using

$$
\frac{\mathrm{dT}}{d Z}=\frac{T_{\text {sed }}\left(Z_{i}\right)-T_{w}}{Z_{i}}
$$

where $T_{\text {sed }}\left(Z_{i}\right)$ is the estimated in situ sediment temperature at subbottom depth $Z_{i}$ and $T_{w}$ is the bottom water temperature determined from hydrographic data. $T_{\text {sed }}\left(Z_{i}\right)$ (and the error) is, in all cases, estimated from the plotted thermal decay curves.

\section{SITE 183}

Measurement $183-4$ provided the only meaningful estimate of in situ sediment temperature at Site 183. The temperature versus time plot clearly shows three instances (A, B, and $\mathrm{C}$ on Figure 2) where the probe temperature increased abruptly and attained thermal equilibrium at higher temperatures. Increase A occurred when the downhole instruments passed from that part of the drill string surrounded by sea water into drill pipe surrounded by warmer sediment, and finally came to rest at the bottom of the drill string just above the bottom of the hole.

Increase $\mathrm{B}$ is caused by deeper penetration of the thermistor probe into either undrilled sediment or a slumped sediment-seawater mixture at the bottom of the hole as the drill string was lowered at the start of the temperature measurement. The gradual temperature rise recorded between $\mathrm{B}$ and $\mathrm{C}$ may be due to the slow sinking of the drill string noted at the drill floor during the measurement.

Temperature increase $\mathrm{C}$ coincides with the start of coring and is believed to be due to the emplacement of previously undrilled sediment around the temperature probe. The best estimate of the insitu sediment temperature at this depth is $9.9 \pm 1{ }^{\circ} \mathrm{C}$, as determined from the equilibrium value approached after the start of coring. It is likely that this value is affected by the generation of some heat in the sediment into the surrounding core barrel and drill collars.

Estimating an equilibrium temperature of $9.9 \pm 1^{\circ} \mathrm{C}$ at a depth of 313 meters, and taking into account a water temperature of $1.5^{\circ} \mathrm{C}$, calculation of a thermal gradient yields $0.0268^{\circ} \mathrm{C} / \mathrm{m}$. This gradient is less than one-half the 


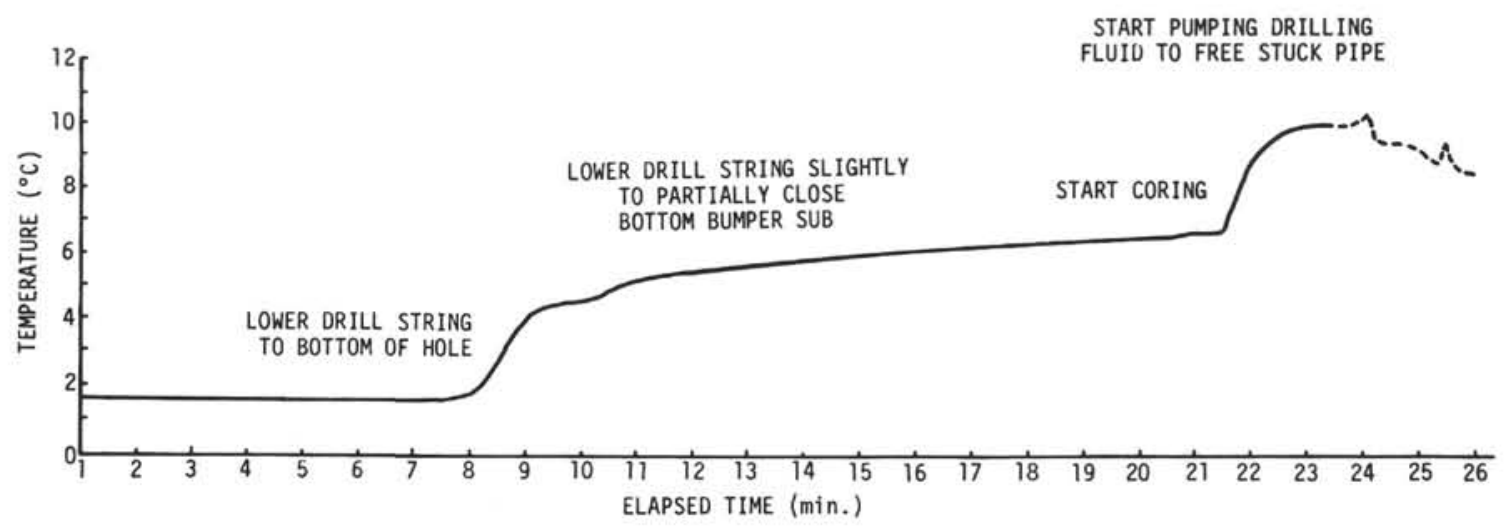

Figure 2. Frequency versus time, measurement number 4, Site 183.

gradient normally found in near-surface marine sediments. The mean conductivity measured in the turbidite sediment below 260 meters is $3.03 \mathrm{mcal} / \mathrm{cm} \mathrm{sec}{ }^{\circ} \mathrm{C}$, giving a heat flow of $0,81 \mathrm{HFU}$ if the entire sediment column has similar conductivity. However, the mean thermal conductivity of the pelagic sediment in the upper 260 meters at this site is almost certainly lower, probably in the range of $2.2 \pm 0.2$ $\mathrm{mcal} / \mathrm{cm} \mathrm{sec}{ }^{\circ} \mathrm{C}$. A more reasonable formation conductivity can be obtained by calculating the weighted mean conductivity on the basis of both sediment type and thickness. The mean conductivity, $K$, is calculated in this manner according to

$$
\frac{1}{\bar{K}}=\frac{\ell_{1}}{K_{1}}+\frac{\ell_{2}}{K_{2}}+\frac{\ell_{3}}{K_{3}}+\ldots+\frac{\ell_{i}}{K_{i}}
$$

where $\ell_{1}, \ell_{2}, \ell_{3}, \ldots ' \ell_{i}$ and $K_{1}, K_{2}, K_{3}, \ldots, K_{i}$ are, respectively, the thicknesses and thermal conductivities of each of the sediment layers from the seafloor to the depth of the temperature measurement. Using this, we calculate a mean formation conductivity of $2.29 \mathrm{mcal} / \mathrm{cm} \mathrm{sec}{ }^{\circ} \mathrm{C}$ and thus a heat flux of $0.61 \mu \mathrm{cal} / \mathrm{cm}^{2} \mathrm{sec}$. This value is much lower than the world average $\left(1.5 \mu \mathrm{cal} / \mathrm{cm}^{2} \mathrm{sec}\right)$ and is slightly higher than the value of $0.4 \mu \mathrm{cal} / \mathrm{cm}^{2} \mathrm{sec}$ measured about $170 \mathrm{~km}$ to the northeast using standard oceanic techniques (Foster, 1962).

\section{SITE 184}

Measurements 184-1 (Figure 3) and, with less reliability, 184-3 (Figure 4) provide estimates of in situ sediment temperature at Site 184. An undisturbed, nearly ideal temperature curve is apparent in Figure 3, with an asymptotic approach to a nearly constant value of $16.25 \pm 0.25^{\circ} \mathrm{C}$ after about 8 minutes at a depth of 174 meters in the undrilled sediment. Data from measurement $184-3$ at 342 meters below bottom defines a similarly shaped, though more disturbed, curve between 7 and 10.5 minutes in Figure 4, after which time a sudden temperature decrease occurs. This abrupt decrease is believed to be caused by the release of the heat flow probe up inside the inner barrel before the completion of the temperature measurement, probably because the sediment was too hard for the heat probe to penetrate. The irregular heating curve just after penetration suggests either that the probe was moving occasionally with respect to the sediment, or that the probe was not buried sufficiently within the sediment to isolate the temperature sensor from thermal disturbances associated with drilling fluid or slumped sediment. The rather uncertain in situ sediment temperature, estimated from the thermal decay curve shown in Figure 4 as $18.5 \pm 10^{\circ} \mathrm{C}$, requires an abrupt decrease (by a factor of six) in the geothermal gradient between 174 and 342 meters, as shown in Figure 5. Such a large decrease is incompatible with the relatively constant thermal conductivity measured between 132 and 600 meters below bottom. The absence of a significant lithologic change between 0 and 603 meters below bottom rules out the possibility that the high thermal gradient between the surface and 174 meters could be due to the presence of very low thermal conductivity material in this interval. In addition, the lowest thermal conductivity value possible for ocean sediment is the conductivity of seawater, approximately $1.4 \mathrm{mcal} / \mathrm{cm} \mathrm{sec}$ ${ }^{\circ} \mathrm{C}$ (Ratcliffe, 1960), which is clearly insufficient to cause the gradient variations noted.

The best estimate for the thermal gradient at Site 184 is thus obtained using the temperature estimate of $16.25^{\circ} \mathrm{C}$ obtained at 174 meters below bottom. The thermal gradient calculated using these data, plus a value of $2.0^{\circ} \mathrm{C}$ for the water temperature obtained from nearby hydrographic data, is $0.082^{\circ} \mathrm{C} / \mathrm{m}$. A heat flow value of 1.77 $\mu \mathrm{cal} / \mathrm{cm}^{2}$ sec has been calculated as the product of the mean thermal conductivity $\left(2.16 \mathrm{mcal} / \mathrm{cm} \mathrm{sec}{ }^{\circ} \mathrm{C}\right)$ and the above thermal gradient.

The only other published heat flow data in the Bering Sea are over $5^{\circ}$ west of Site 184 and thus may provide a poor basis for comparison. All five of these heat flow values fall in the range 0.9 to $1.3 \mu \mathrm{cal} / \mathrm{cm}^{2} \mathrm{sec}$ (Foster, 1962). The calculated geothermal flux of $1.77 \mu \mathrm{cal} / \mathrm{cm}^{2} \mathrm{sec}$ is slightly higher than the average heat flow through ocean basins (1.3 $\mu \mathrm{cal} / \mathrm{cm}^{2} \mathrm{sec}$, Langseth and Von Herzen, 1971), and is more typical of heat flow values frequently obtained in marginal basins behind active island arcs, such as the Bering Sea. Heat flow in Kamchatka Basin, western Bering Sea, is very high and values as high as $2.64 \mathrm{HFU}$ have been reported (see Chapter 13).

\section{SITE 185}

Although five of the seven downhole temperature runs were successful in returning data, only measurements $185-1$ and 185-5 appear to be useful for the purpose of estimating 


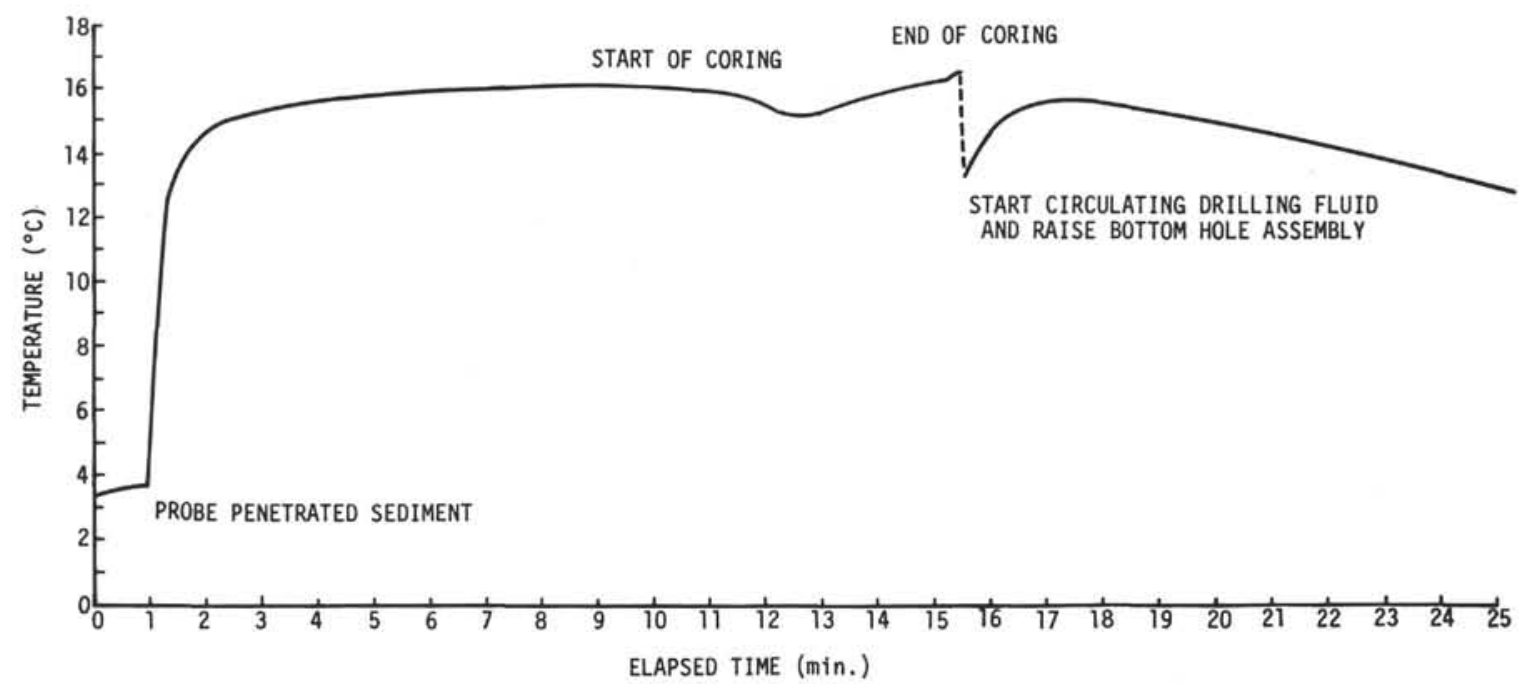

Figure 3. Frequency versus time, measurement number 1, Site 184.

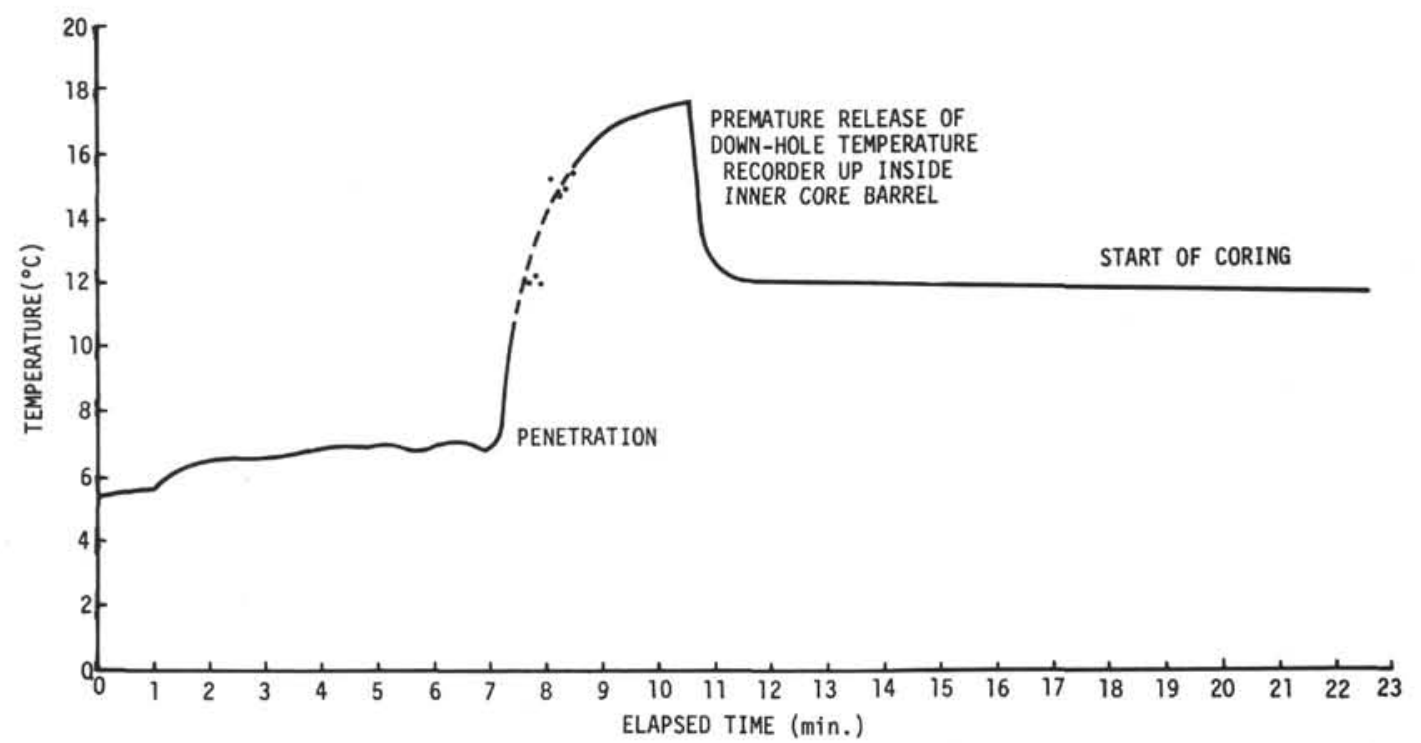

Figure 4. Frequency versus time, measurement number 3, Site 184.

in situ sediment temperatures and heat flow. Measurement 185-1 (Figure 6) was made at a depth of only 16 meters below bottom and suffered from thermo-mechanical disturbances caused by the slow sinking of the bottom-hole assembly and heat probe into the soft sediment and by additional periodic movements of the probe due to the vertical oscillations of the drill string in response to surface wave motion and ship motion.

During measurement 185-4 (Figure 7) the heat probe assembly appears to have been released up inside the inner core barrel before acquisition of enough temperature data to allow extrapolation of the warming curve to obtain an equilibrium temperature. It appears probable from the rapid initial temperature increase that the actual in situ sediment temperature is substantially higher than the maximum observed temperature $\left(21.1^{\circ} \mathrm{C}\right)$. The rapid temperature increase may also be evidence of significant frictional heating during penetration; however, such heating is not in evidence in other measurements. Thus a mean geothermal gradient at least as large as $0.0504^{\circ} \mathrm{C} / \mathrm{m}$ is believed to exist in the upper 381 meters.

The temperature data acquired during measurement 185-5 (Figure 8) show a well-defined heating curve approaching an equilibrium value of $25.3^{\circ} \mathrm{C}$ at a depth of 662 meters. Several factors suggest that while this may be a valid temperature measurement of the material around the probe, it probably does not represent the in situ sediment temperature at this depth. First, the thermal gradient calculated between 381 and 662 meters using temperature values of $21.1^{\circ} \mathrm{C}$ and $25.3^{\circ} \mathrm{C}$, respectively, is only $0.015^{\circ} \mathrm{C} / \mathrm{m}$, less than a third of the minimum gradient between 0 and 381 meters below bottom. Although thermal conductivity data are not available between 232 and 664 meters, the relatively homogeneous lithology and lack of any indication of a more than three-fold conductivity increase below 381 meters suggests that the temperature measurement at 662 meters is too low by about $5^{\circ} \mathrm{C}$. Further support for this theory is found in the sudden 
TEMPERATURE $\left({ }^{\circ} \mathrm{C}\right)$

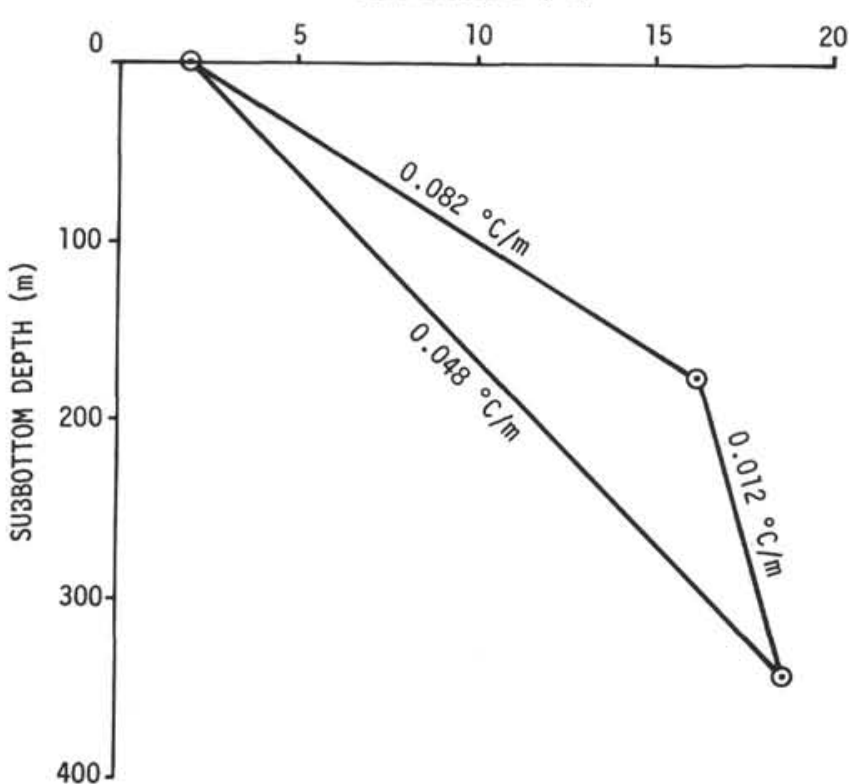

temperature increase when the drill string was lowered to the bottom of the hole at the start of coring. It appears that coring succeeded in packing newly drilled sediment around the probe which was substantially hotter than the material in which the probe had been previously. Thus the observed maximum temperature of $29.5^{\circ} \mathrm{C}$ is again a minimum in situ sediment temperature.

Measurements 185-6 and 185-7 are from hard mudstones into which the temperature probe could not penetrate. Thus the temperature curves (typified by Figure 9) do not show a typical warming curve after the drill string is lowered, but rather reflect the mean temperature of the mixture of mud and seawater just above the bottom of the drill hole.

Bottom water temperature and sediment temperature data from measurements $185-4$ and $185-5$ are plotted versus depth in Figure 10. The gradients calculated from the sediment surface to 381 and 662 meters below bottom are 0.0504 and $0.0417^{\circ} \mathrm{C} / \mathrm{m}$, respectively. Due to evidence for nearly constant thermal conductivity from 0 to 670 meters, it can be stated that the lower gradient below 381 meters is due to the maximum observed temperature at 662 meters

Figure 5. Temperature versus depth, Site 184.

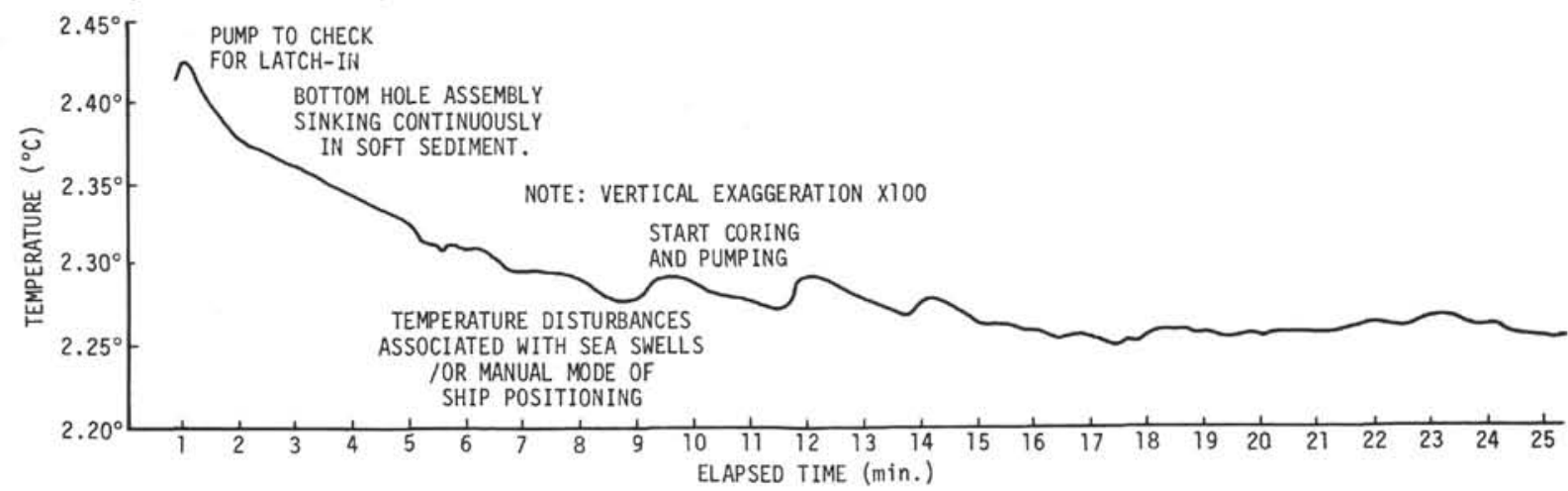

Figure 6. Frequency versus time, measurement number 1, Site 185.

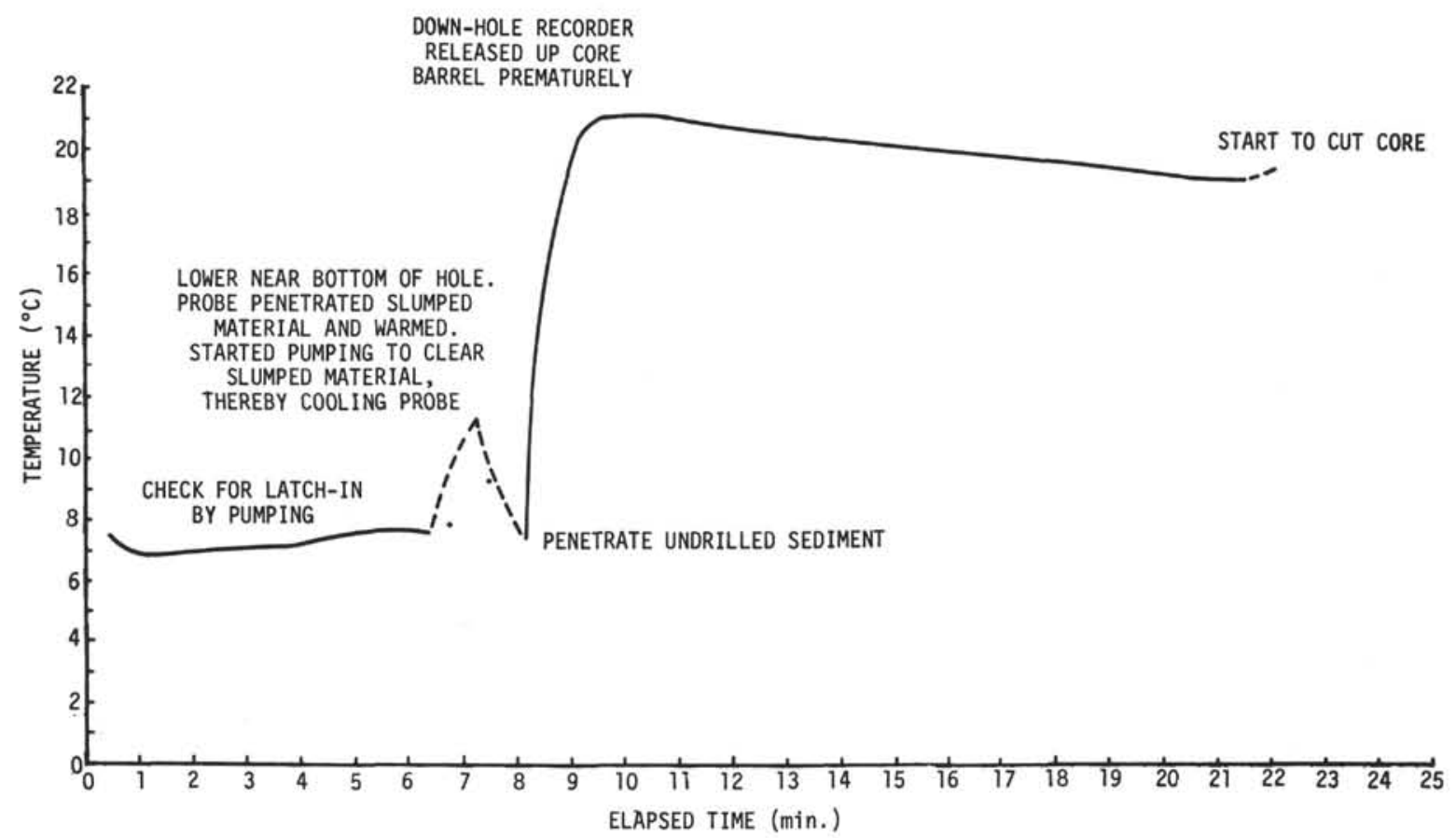

Figure 7. Frequency versus time, measurement number 4, Site 185. 


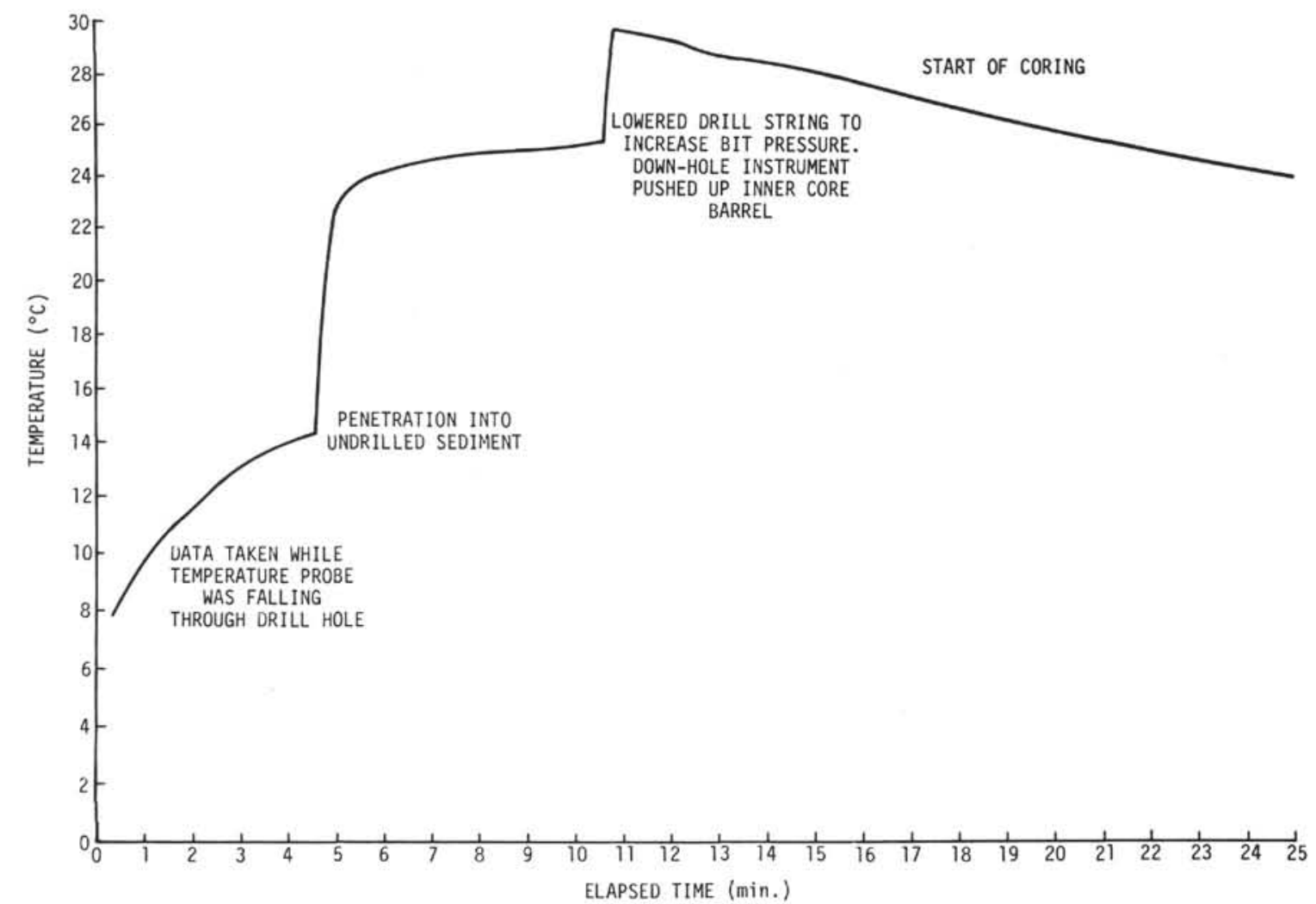

Figure 8. Frequency versus time, measurement number 5, Site 185.

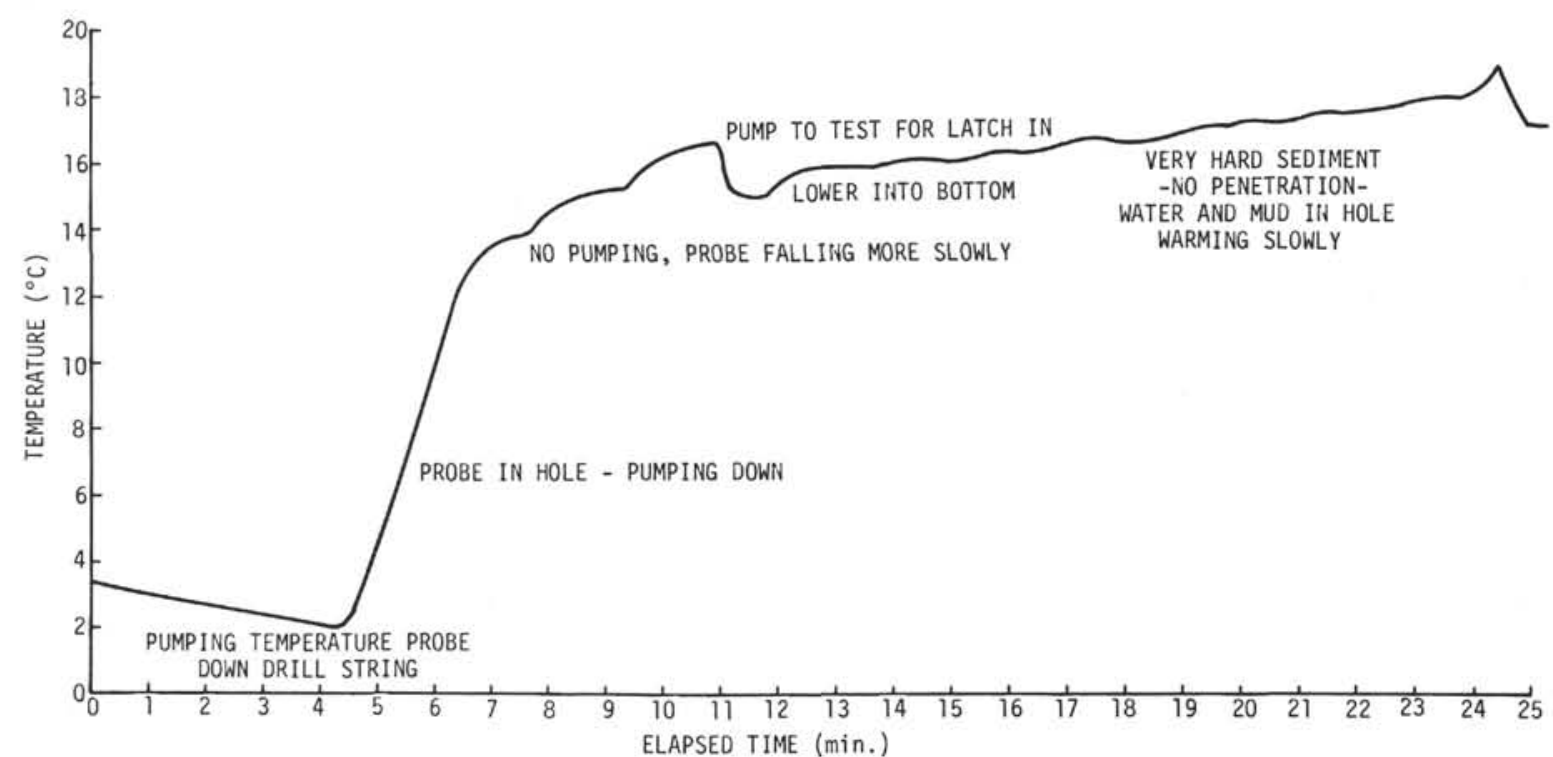

Figure 9. Frequency versus time, measurement number 6, Site 185.

being lower than the true in situ sediment temperature. Thus only an estimate of the minimum heat flow is available for this site. Using the gradient of $0.0504^{\circ} \mathrm{C} / \mathrm{m}$ and the mean thermal conductivity of $2.04 \mu \mathrm{cal} / \mathrm{cm}^{2} \mathrm{sec}$. we compute a minimum heat flux of $1.04 \mu \mathrm{cal} / \mathrm{cm}^{2} \mathrm{sec}$.

Comments about this value are similar to those about the heat flow value obtained at Site 184 . Specifically, this minimum heat flow value is lower than either the mean heat flow through ocean or marginal basins, but is within the range of values measured by Foster (1962) in the Bering Sea about $5^{\circ}$ further west.

\section{Summary of Heat Flow Data:}

The heat flow measurements at Sites 183, 184, and 185 are summarized in Table 2 . These values are based on geothermal gradients established using only one or two downhole temperatures; therefore, the possible error is large. 


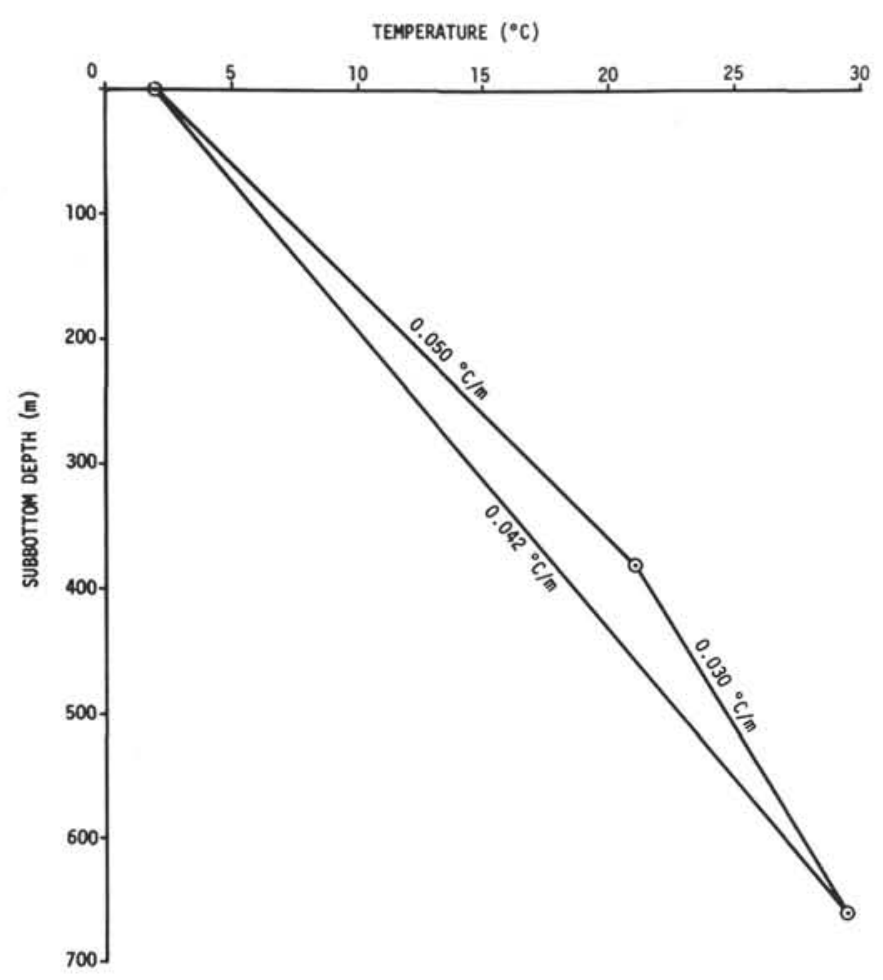

Figure 10. Temperature versus depth, Site 185.

TABLE 2

Summary of Leg 19 Heat Flow Data

\begin{tabular}{cccc}
\hline Site & $\begin{array}{c}\text { Thermal Gradient } \\
\left({ }^{\circ} \mathrm{C} / \mathrm{m}\right)\end{array}$ & $\begin{array}{c}\text { Thermal Conductivity } \\
\left(\mathrm{mcal} / \mathrm{cm} \mathrm{sec}^{\circ} \mathrm{C}\right)\end{array}$ & $\begin{array}{c}\text { Heat Flow } \\
\left(\mu \mathrm{cal} / \mathrm{cm}^{2} \mathrm{sec}\right)\end{array}$ \\
\hline 183 & 0.027 & $2.29^{\mathrm{a}}$ & 0.61 \\
184 & 0.082 & 2.16 & 1.77 \\
185 & $\geqslant 0.050$ & 2.04 & $\geqslant 1.02$ \\
\hline
\end{tabular}

${ }^{\mathrm{a}}$ Conductivity of $2.2 \mathrm{mcal} / \mathrm{cm} \mathrm{sec}{ }^{\circ} \mathrm{C}$ assumed for upper 260 meters of pelagic sediment.

\section{THERMAL CONDUCTIVITY DATA}

\section{Discussion of Measurement Technique}

Thermal conductivity measurements were made on the sediment cores aboard ship using the transient line source technique described by Von Herzen and Maxwell (1959). One or two measurements were made through the core liner each time a core was retrieved whenever time permitted. No attempt was made, nor would it have been possible, due to the core liner, to locate the measurements in specific sediment types. Therefore, some conductivity measurements were made in sediment types which may constitute only a small fraction of the entire sedimentary column, and thus should not be given the same weight as other values. In addition, it is highly probable that a small fraction of the conductivity values do not represent downhole in situ values due to the effects of mechanical disturbance of the sediments during coring.

For these reasons one must exercise a degree of caution both in interpreting the data summarized in the following tables and shown graphically in Figures 11 through 16 . The thermal conductivity values obtained aboard ship must be corrected back to the in situ value corresponding to the pressure and temperature conditions beneath the seafloor.
The temperature and pressure corrections $\Delta K_{T}$ and $\Delta K_{p}$ were calculated as suggested by Ratcliffe (1960) using

$$
\begin{gathered}
\Delta K_{T}=K_{o b s}\left(T_{w}+Z_{H} \cdot \frac{d t}{d z}\right) / 400 \\
\Delta K_{p}=K_{o b s}\left(Z_{w}+\rho_{s e d} \cdot Z_{H}\right) / 182900
\end{gathered}
$$

where

$$
\begin{aligned}
K_{o b s} & =\text { observed thermal conductivity }(\mathrm{mcal} / \mathrm{cm} \mathrm{sec} \\
T_{w} & =\text { bottom water temperature }\left({ }^{\circ} \mathrm{C}\right), \\
Z_{H} & =\text { subbottom depth }(\mathrm{m}), \\
d T / d Z & =\text { average geothermal gradient }\left({ }^{\circ} \mathrm{C} / \mathrm{m}\right), \\
T_{L} & =\text { core temperature during the measurement } \\
& \left({ }^{\circ} \mathrm{C}\right), \\
Z_{w} & =\text { water depth }(\mathrm{m}), \text { and } \\
\rho_{\text {sed }} & =\text { average sediment density }(\mathrm{gm} / \mathrm{cc}) .
\end{aligned}
$$

At Sites 183, 184, and 185, downhole temperature measurements were used to estimate the mean geothermal gradient (Table 2), and bottom water temperatures of 1.5 , 2.0 , and $1.9^{\circ} \mathrm{C}$, respectively, were estimated from hydrographic data. At the remaining sites, the geothermal gradient was assumed to be equal to the average thermal gradient normally observed in ocean sediments $\left(0.06^{\circ} \mathrm{C} / \mathrm{m}\right)$ and a bottom water temperature of $1.9^{\circ} \mathrm{C}$ was assumed from data presented by Sverdrup et al. (1942, p. 753). The error in the corrected thermal conductivity due to failure to estimate the geothermal gradient accurately increases linearly with subbottom depth of the measurement; for the maximum measurement depth $(685 \mathrm{~m})$ considered here and an unrealistically large gradient error of a factor of two, the maximum error in the corrected thermal conductivity value would be about 6.4 per cent. This emphasizes the necessity for, and interrelation of, conductivity and temperature data-both are necessary in order to extrapolate sediment temperature to depths greater than those for which temperature data exists.

A density of $2.0 \mathrm{gm} / \mathrm{cc}$ was assumed for all of the sedimentary types at all of the sites in order to calculate the pressure correction. This value is 0.4 to $0.5 \mathrm{gm} / \mathrm{cc}$ higher than the measured bulk densities and should be reduced in

\begin{tabular}{|c|c|c|c|c|c|}
\hline \multirow[b]{2}{*}{ Core } & \multirow[b]{2}{*}{ Section } & \multirow{2}{*}{$\begin{array}{l}\text { Position } \\
\quad(\mathrm{cm})\end{array}$} & \multirow{2}{*}{$\begin{array}{l}\text { Subbottom } \\
\text { Depth } \\
\text { (m) }\end{array}$} & \multicolumn{2}{|c|}{$\begin{array}{l}\text { Conductivity } \\
\left(\mathrm{mcal} / \mathrm{cm} \mathrm{sec}{ }^{\circ} \mathrm{C}\right)\end{array}$} \\
\hline & & & & Observed & Corrected \\
\hline 31 & 1 & 127 & 296 & 3.10 & 3.10 \\
\hline 31 & 2 & 115 & 298 & 3.11 & 3.11 \\
\hline 32 & 1 & 125 & 314 & 2.89 & 2.89 \\
\hline
\end{tabular}
subsequent calculations. Failure to use the lower density causes the corrected conductivity to be too high by less than 0.2 per cent.

\section{Presentation of Data}

\section{SITE 183}

Only three conductivity measurements (Table 3 ) were made on sediment cored between 296 and 314 meters below bottom at Site 183. These sediments consisted of

TABLE 3

Leg 19 Thermal Conductivity Data-Site 183 
compact, plastic, olive gray clay with interbedded silts and fine-grained sands. The values obtained are uniformly high $\left(2.89-3.11 \mathrm{mcal} / \mathrm{cm} \mathrm{sec}{ }^{\circ} \mathrm{C}\right)$ and may be representative of the turbidite material below 260 meters; above 260 meters the sediments are predominantly pelagic diatom oozes and clays, which are generally characterized by variable but lower conductivity values. No conductivity data was obtained from these pelagic sequences.

\section{SITE 184}

Thermal conductivity values (Table 4 and Figure 11) measured in the predominantly clay-rich diatom oozes at Site 184 are relatively constant between 132 and 400 meters below bottom, with only two values less than 1.9 $\mathrm{mcal} / \mathrm{cm} \mathrm{sec}{ }^{\circ} \mathrm{C}$ and no values greater than $2.4 \mathrm{mcal} / \mathrm{cm} \mathrm{sec}$ ${ }^{\circ} \mathrm{C}$. The low values, 1.74 and $1.75 \mathrm{mcal} / \mathrm{cm} \mathrm{sec}{ }^{\circ} \mathrm{C}$, were measured in a layer of volcanic sand and pumice (169 m)

TABLE 4

Leg 19 Thermal Conductivity Date-Site 184

\begin{tabular}{|c|c|c|c|c|c|}
\hline \multirow[b]{2}{*}{ Core } & \multirow[b]{2}{*}{ Section } & \multirow{2}{*}{$\begin{array}{l}\text { Position } \\
\quad(\mathrm{cm})\end{array}$} & \multirow{2}{*}{$\begin{array}{l}\text { Subbottom } \\
\text { Depth } \\
\text { (m) }\end{array}$} & \multicolumn{2}{|c|}{$\begin{array}{c}\text { Conductivity } \\
\left(\mathrm{mcal} / \mathrm{cm} \mathrm{sec}{ }^{\circ} \mathrm{C}\right)\end{array}$} \\
\hline & & & & Observed & Corrected \\
\hline 2 & 3 & 56 & 132 & 2.19 & 2.21 \\
\hline 2 & 5 & - & 135 & 2.17 & 2.19 \\
\hline 2 & 6 & - & 136 & 2.20 & 2.21 \\
\hline 3 & 1 & 65 & 147 & 1.98 & 1.99 \\
\hline 3 & 4 & 65 & 151 & 1.91 & 1.93 \\
\hline 4 & 1 & - & 166 & 2.15 & 2.20 \\
\hline 4 & 3 & - & 169 & 1.72 & 1.75 \\
\hline 6 & 1 & - & 203 & 2.15 & 2.21 \\
\hline 6 & 3 & 69 & 206 & 2.32 & 2.38 \\
\hline 7 & 2 & 78 & 223 & 2.17 & 2.24 \\
\hline 7 & 4 & 58 & 226 & 2.26 & 2.33 \\
\hline 8 & 2 & 49 & 242 & 1.84 & 1.91 \\
\hline 8 & 4 & 49 & 245 & 1.88 & 1.95 \\
\hline 9 & 2 & 51 & 251 & 1.67 & 1.74 \\
\hline 9 & 4 & 56 & 254 & 2.12 & 2.20 \\
\hline 10 & 2 & 50 & 279 & 2.00 & 2.09 \\
\hline 10 & 4 & 54 & 282 & 2.30 & 2.40 \\
\hline 11 & 2 & 62 & 297 & 2.21 & 2.32 \\
\hline 11 & 4 & 49 & 300 & 2.23 & 2.33 \\
\hline 12 & 2 & 110 & 336 & 1.87 & 2.00 \\
\hline 12 & 3 & 58 & 337 & 2.21 & 2.35 \\
\hline 13 & 2 & 58 & 344 & 2.24 & 2.38 \\
\hline 13 & 3 & 61 & 346 & 2.02 & 2.13 \\
\hline 14 & 2 & 106 & 382 & 2.10 & 2.26 \\
\hline 14 & 3 & 73 & 384 & 1.94 & 2.09 \\
\hline 14 & 4 & 45 & 385 & 1.95 & 2.06 \\
\hline 14 & 4 & 100 & 386 & 2.00 & 2.10 \\
\hline 15 & 2 & 40 & 391 & 1.88 & 2.01 \\
\hline 15 & 2 & 95 & 391 & 1.92 & 2.03 \\
\hline 16 & 2 & 20 & 429 & 1.89 & 2.04 \\
\hline 16 & 2 & 90 & 429 & 1.87 & 2.01 \\
\hline 17 & 2 & 99 & 466 & 1.85 & 2.00 \\
\hline 18 & 1 & 100 & 503 & 2.04 & 2.22 \\
\hline 19 & 2 & 70 & 513 & 2.08 & 2.26 \\
\hline 19 & 2 & 80 & 513 & 1.88 & 2.04 \\
\hline 20 & 2 & 80 & 539 & 1.95 & 2.14 \\
\hline 20 & 3 & 80 & 541 & 1.91 & 2.11 \\
\hline 20 & 4 & 80 & 542 & 2.07 & 2.26 \\
\hline 21 & 3 & 80 & 571 & 2.14 & 2.35 \\
\hline 22 & 2 & 113 & 596 & 1.97 & 2.18 \\
\hline 22 & 3 & 30 & 597 & 2.16 & 2.41 \\
\hline 22 & 4 & 80 & 598 & 2.18 & 2.42 \\
\hline 22 & 5 & 59 & 598 & 2.08 & 2.31 \\
\hline 22 & 6 & 80 & 599 & 2.08 & 2.30 \\
\hline
\end{tabular}

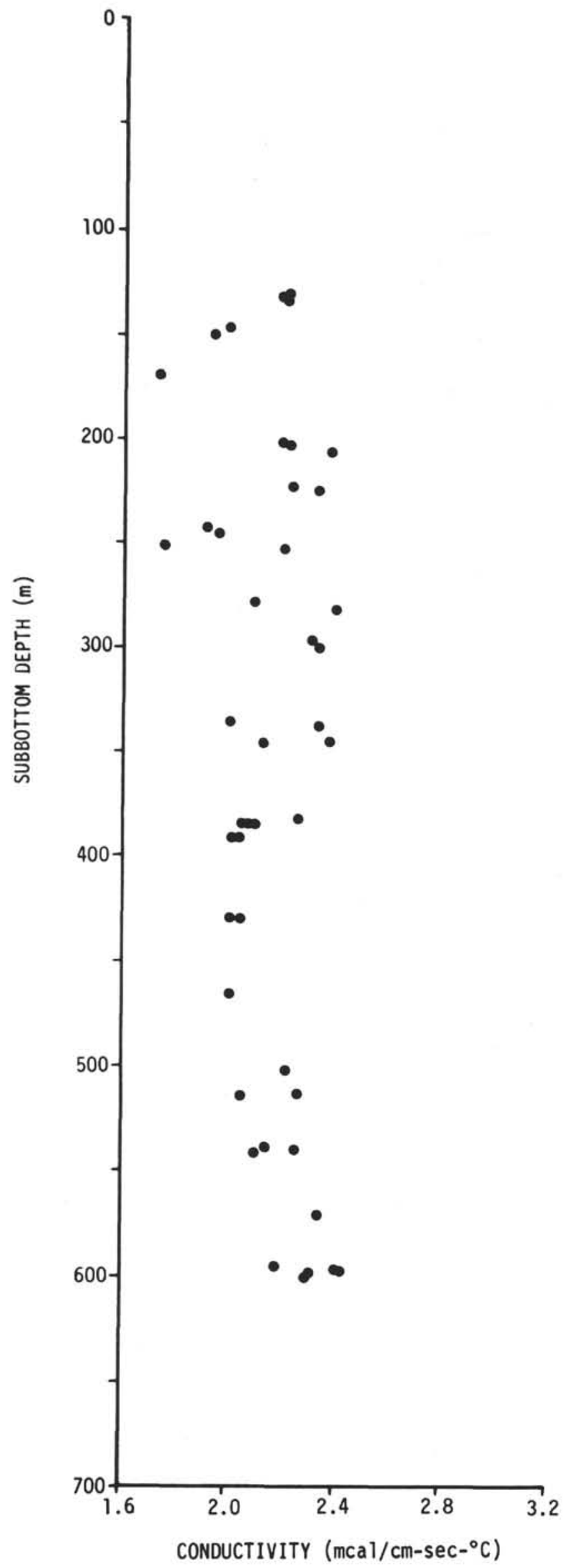

Figure 11. Thermal conductivity versus depth below bottom, Site 184. 
and in a highly disturbed region of clay-bearing diatom ooze $(251 \mathrm{~m})$, respectively. Much of the remaining variability in the upper 400 meters can probably be attributed to the frequent occurrence of layers of volcanic and terrestrial sand and silt, as well as ash layers and pumice erratics within the sedimentary section.

Between 400 and 600 meters, the thermal conductivity appears to increase slightly with depth and to be less variable, in good agreement with the observed downward increase in clay content, density, and induration, as well as with a downward decrease in the amount of interbedded volcanic sand and ash.

\section{SITE 185}

Thermal conductivity values (Table 5 and Figure 12) in the upper 227 meters of site 185 are relatively uniform, with a mean of $2.04 \mathrm{mcal} / \mathrm{cm} \mathrm{sec}{ }^{\circ} \mathrm{C}$. The sediment between 227 and 664 meters below bottom was too lithified for conductivity measurements using the needle-probe technique. At about 664 meters (core 20), softer material was encountered, thus permitting a few additional measurements which fall within the range of values observed in the upper 227 meters. This fact, along with the observation that the entire section to a depth of 600 meters consists of diatom ooze with variable admixtures of silt and clay, suggests that the thermal conductivity may be relatively constant throughout the section. On the other hand, these deeper measurements were made in material with a somewhat higher acoustic velocity (and density) than was typical of the sediment between 0 and 227 meters. It is possible that the exsolution of gas in these deeper sediments may

TABLE 5

Leg 19 Thermal Conductivity Data-Site 185

\begin{tabular}{|c|c|c|c|c|c|}
\hline \multirow[b]{2}{*}{ Core } & \multirow[b]{2}{*}{ Section } & \multirow{2}{*}{$\begin{array}{l}\text { Position } \\
\quad(\mathrm{cm})\end{array}$} & \multirow{2}{*}{$\begin{array}{l}\text { Subbottom } \\
\text { Depth } \\
\text { (m) }\end{array}$} & \multicolumn{2}{|c|}{$\begin{array}{c}\text { Conductivity } \\
\left(\mathrm{mcal} / \mathrm{cm} \sec { }^{\circ} \mathrm{C}\right)\end{array}$} \\
\hline & & & & Observed & Corrected \\
\hline 1 & 2 & 80 & 2 & 2.01 & 1.97 \\
\hline 1 & 4 & 80 & 5 & 2.12 & 2.11 \\
\hline 4 & 3 & 76 & 39 & 2.14 & 2.14 \\
\hline 4 & 4 & 79 & 40 & 2.13 & 2.11 \\
\hline 4 & 5 & 80 & 42 & 2.13 & 2.12 \\
\hline 5 & 1 & 113 & 63 & 1.90 & 1.90 \\
\hline 6 & 2 & 80 & 93 & 1.89 & 1.90 \\
\hline 6 & 4 & 80 & 96 & 2.15 & 2.17 \\
\hline 6 & 6 & 80 & 99 & 1.83 & 1.84 \\
\hline 7 & 2 & 80 & 131 & 2.00 & 2.02 \\
\hline 7 & 3 & 80 & 133 & 1.98 & 1.99 \\
\hline 7 & 4 & 80 & 134 & 2.11 & 2.13 \\
\hline 8 & 2 & 80 & 169 & 2.13 & 2.17 \\
\hline 8 & 4 & 80 & 172 & 1.93 & 1.96 \\
\hline 10 & 2 & 80 & 224 & 1.85 & 1.87 \\
\hline 10 & 3 & 80 & 226 & 2.07 & 2.10 \\
\hline 10 & 4 & 80 & 227 & 2.08 & 2.10 \\
\hline 20 & 2 & 80 & 664 & 2.06 & 2.18 \\
\hline 20 & 3 & 80 & 666 & 2.06 & 2.18 \\
\hline 20 & 4 & 80 & 667 & 1.83 & 1.94 \\
\hline 20 & 6 & 80 & 670 & 2.57 & 2.73 \\
\hline 21 & 1 & 120 & 672 & 2.73 & 2.91 \\
\hline 21 & 2 & 51 & 673 & 2.56 & 2.74 \\
\hline 21 & 3 & 61 & 675 & 2.59 & 2.76 \\
\hline 23 & 1 & 120 & 684 & 2.81 & 3.02 \\
\hline 23 & 2 & 49 & 685 & 2.59 & 2.74 \\
\hline
\end{tabular}

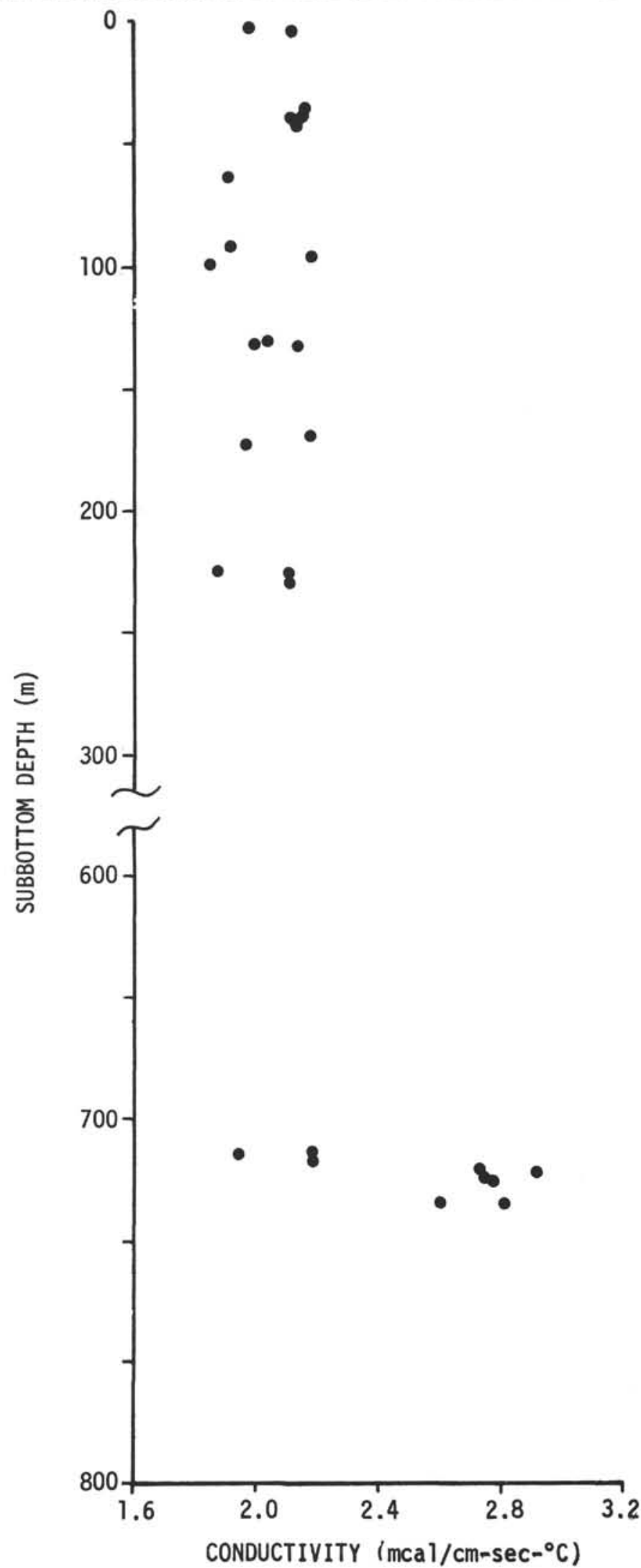

Figure 12. Thermal conductivity versus depth below bottom, Site 185.

have reduced the shipboard conductivity values below the in situ conductivity. 
A short section of gas-bearing clayey, diatomaceous sediments which could be penetrated by the conductivity probe were encountered below 667 meters at Site 185 . These sediments were highly disturbed, both by the coring process and by the expansion of interstitial gases. Although the conductivity measurements were made as soon as possible, they are undoubtedly and unavoidably affected by the creation and movement of gas bubbles within the sediment. The presence of interstitial gas bubbles would be expected to reduce the thermal conductivity of the sediment; however, the mechanical and mass transport effects of bubble growth and gas diffusion must override the insulating effects, for the observed mean conductivity is actually higher than conductivity values measured on nongassy sediments having similar composition. Thus the relationship of the observed values to in situ conductivity in unknown.

\section{SITE 188}

Conductivity values (Table 6 and Figure 13) in the upper 285 meters at Site 188 vary between a value of 1.64 $\mathrm{mcal} / \mathrm{cm} \mathrm{sec}{ }^{\circ} \mathrm{C}$ measured in clay-rich diatom silt with interbedded muds and a value of 2.21 in silt- and clay-rich diatom ooze. A low value of $1.73 \mathrm{mcal} / \mathrm{cm} \mathrm{sec}{ }^{\circ} \mathrm{C}$ was obtained in 90 per cent pure diatom ooze at a depth of 285 meters. The observed variability in conductivity again reflects the variability of the sediment types, principally unconsolidated and semi-consolidated diatom ooze, silt-rich diatom ooze, diatom silt, and interbedded layers of volcanic sand, silt, and ash. Conductivity, density, and acoustic velocity over this interval are low and relatively uniform, with the exception of the more clay-rich layers, where increases in all three parameters are noted.

TABLE 6

Leg 19 Thermal Conductivity Data-Site 188

\begin{tabular}{|c|c|c|c|c|c|}
\hline \multirow[b]{2}{*}{ Core } & \multirow[b]{2}{*}{ Section } & \multirow{2}{*}{$\begin{array}{l}\text { Position } \\
(\mathrm{cm})\end{array}$} & \multirow{2}{*}{$\begin{array}{l}\text { Subbottom } \\
\text { Depth } \\
\text { (m) }\end{array}$} & \multicolumn{2}{|c|}{$\begin{array}{c}\text { Conductivity } \\
\left(\mathrm{mcal} / \mathrm{cm} \mathrm{sec}{ }^{\circ} \mathrm{C}\right)\end{array}$} \\
\hline & & & & Observed & Corrected \\
\hline 3 & 3 & 70 & 33 & 2.23 & 2.21 \\
\hline 6 & 3 & 80 & 128 & 1.76 & 1.79 \\
\hline 6 & 3 & 80 & 128 & 1.68 & 1.70 \\
\hline 7 & 3 & - & 174 & 1.77 & 1.80 \\
\hline 7 & 6 & 80 & 179 & 1.82 & 1.84 \\
\hline 8 & 2 & 80 & 224 & 1.98 & 2.02 \\
\hline 9 & 2 & 70 & 285 & 1.73 & 1.79 \\
\hline
\end{tabular}

SITE 190

Conductivity values at Site 190 (Table 7 and Figure 14) vary between 1.92 and $2.88 \mathrm{mcal} / \mathrm{cm} \mathrm{sec}{ }^{\circ} \mathrm{C}$, with higher values measured in the upper, more clay-rich sediments and lower values obtained at greater depths in more diatomaceous material. The existence of thin layers of graded volcanic sand and silt and diatom ooze within the diatombearing to diatom-rich clay precludes the establishment of a good correlation between lithology and conductivity at this site.

The observed general downward increase in thermal conductivity from $2.02 \mathrm{mcal} / \mathrm{cm} \mathrm{sec}{ }^{\circ} \mathrm{C}$ at about 25 meters to $2.64 \mathrm{mcal} / \mathrm{cm} \mathrm{sec}{ }^{\circ} \mathrm{C}$ at 90 meters correlates well with similar increases in acoustic velocity and density observed

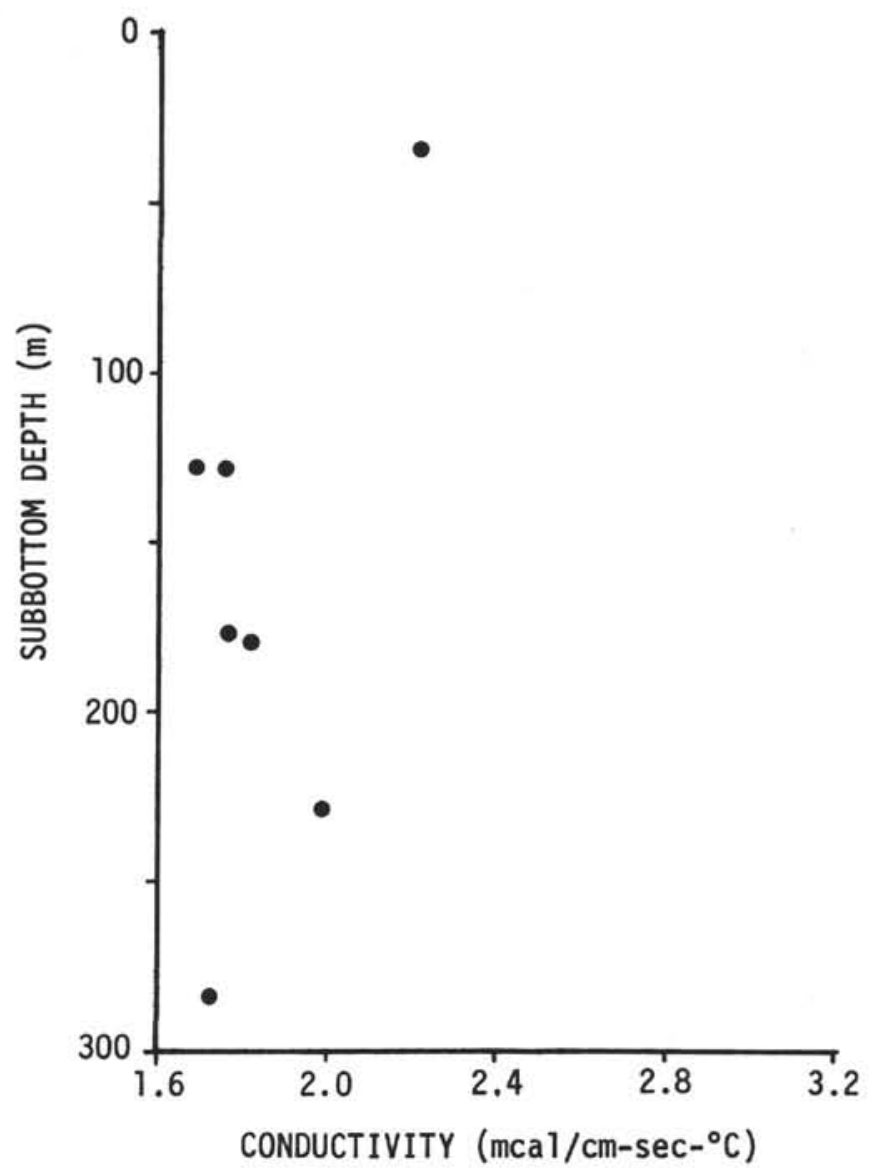

Figure 13. Thermal conductivity versus depth below bottom, Site 188.

TABLE 7

Leg 19 Thermal Conductivity Data-Site 190

\begin{tabular}{|c|c|c|c|c|c|}
\hline \multirow[b]{2}{*}{ Core } & \multirow[b]{2}{*}{ Section } & \multirow{2}{*}{$\begin{array}{l}\text { Position } \\
(\mathrm{cm})\end{array}$} & \multirow{2}{*}{$\begin{array}{l}\text { Subbottom } \\
\text { Depth } \\
\text { (m) }\end{array}$} & \multicolumn{2}{|c|}{$\begin{array}{c}\text { Conductivity } \\
\left(\mathrm{mcal} / \mathrm{cm} \mathrm{sec}{ }^{\circ} \mathrm{C}\right)\end{array}$} \\
\hline & & & & Observed & Corrected \\
\hline 4 & 2 & 70 & 26 & 2.19 & 2.17 \\
\hline 5 & 2 & 80 & 35 & 2.02 & 2.02 \\
\hline 6 & 2 & 70 & 45 & 2.30 & 2.32 \\
\hline 7 & 2 & 80 & 77 & 2.60 & 2.65 \\
\hline 8 & 4 & 80 & 89 & 2.63 & 2.64 \\
\hline 9 & 2 & 80 & 114 & 2.55 & 2.61 \\
\hline 10 & 2 & 80 & 152 & 2.88 & 2.97 \\
\hline 11 & 2 & 80 & 199 & 2.62 & 2.70 \\
\hline 11 & 4 & 80 & 202 & 1.99 & 2.07 \\
\hline 12 & 2 & 80 & 227 & 2.30 & 2.38 \\
\hline 12 & 4 & 80 & 230 & 2.38 & 2.47 \\
\hline 13 & 3 & 57 & 332 & 1.85 & 1.92 \\
\hline 14 & 5 & 83 & 428 & 1.76 & 1.87 \\
\hline
\end{tabular}

in the upper 100 meters. The high conductivity value of $2.88 \mathrm{mcal} / \mathrm{cm} \mathrm{sec}{ }^{\circ} \mathrm{C}$ was obtained in a layer of well-sorted volcanic silt at 152 meters and probably does not indicate a continuing downward increase, as also suggested by the slight decrease in density, acoustic velocity, and clay content below 100 meters. Near 200 meters, two markedly different conductivity values, 2.07 and $2.70 \mathrm{mcal} / \mathrm{cm} \mathrm{sec}$ ${ }^{\circ} \mathrm{C}$, were obtained in diatom ooze ( $10 \%$ clay) and diatomrich silty clay ( $40 \%$ clay), respectively. Low conductivity 


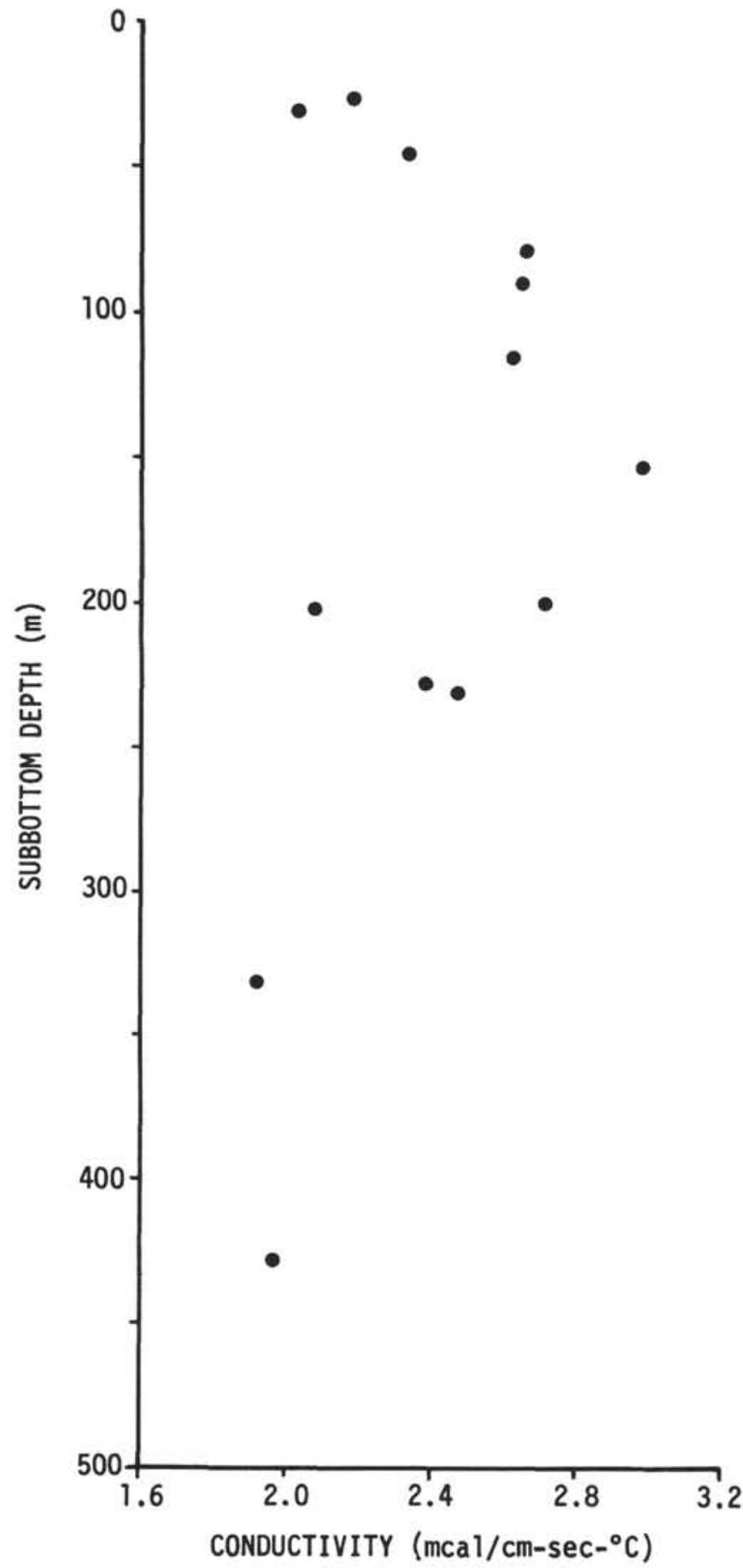

Figure 14. Thermal conductivity versus depth below bottom, Site 190.

values at 332 and 430 meters probably reflect the downward-increasing diatom content.

\section{SITE 191}

Only one value of $3.03 \mathrm{mcal} / \mathrm{cm} \mathrm{sec}{ }^{\circ} \mathrm{C}$ was obtained in sand-bearing silty clay at a depth of 18 meters below bottom. The predominant sediment type to a depth of over 500 meters at this site is diatom-bearing silty clay and diatom ooze which generally appears to have a significantly lower thermal conductivity. Thus, the value of 3.03 $\mathrm{mcal} / \mathrm{cm} \mathrm{sec}{ }^{\circ} \mathrm{C}$ would not be representative for the entire sedimentary section.

\section{SITE 192}

Thermal conductivity values at Site 192 (Table 8 and Figure 15) range from 1.91 to $2.32 \mathrm{mcal} / \mathrm{cm} \mathrm{sec}{ }^{\circ} \mathrm{C}$, excluding a value of 1.79 obtained in a disturbed area of Core 7 in the vicinity of volcanic erratics and ash. The mean conductivity in the upper 126 meters of diatomaceous silty clay (excluding the value of 1.79 ) is $2.19 \mathrm{mcal} / \mathrm{cm} \mathrm{sec}{ }^{\circ} \mathrm{C}$, in good agreement with measurements in similar lithologies at other sites. Conductivity values are slightly lower in the diatom ooze between 209 and 393 meters below bottom $\left(\right.$ mean $\left.=2.04 \mathrm{mcal} / \mathrm{cm} \mathrm{sec}{ }^{\circ} \mathrm{C}\right)$, and both conductivity and density tend to increase with depth, probably reflecting increased degrees of induration. Some of the variability of the data in the upper section is at least partially due to the unusually severe coring disturbances noted at this site.

TABLE 8

Leg 19 Thermal Conductivity Data-Site 192

\begin{tabular}{|c|c|c|c|c|c|}
\hline \multirow[b]{2}{*}{ Core } & \multirow[b]{2}{*}{ Section } & \multirow{2}{*}{$\begin{array}{l}\text { Position } \\
\quad(\mathrm{cm})\end{array}$} & \multirow{2}{*}{$\begin{array}{l}\text { Subbottom } \\
\text { Depth } \\
\text { (m) }\end{array}$} & \multicolumn{2}{|c|}{$\begin{array}{c}\text { Conductivity } \\
\left(\mathrm{mcal} / \mathrm{cm} \mathrm{sec}{ }^{\circ} \mathrm{C}\right)\end{array}$} \\
\hline & & & & Observed & Corrected \\
\hline 2 & 3 & 70 & 5 & 2.07 & 2.06 \\
\hline 3 & 2 & 80 & 12 & 2.20 & 2.17 \\
\hline 4 & 2 & 70 & 21 & 2.28 & 2.23 \\
\hline 5 & 2 & 80 & 30 & 2.35 & 2.32 \\
\hline 6 & 2 & 80 & 57 & 2.04 & 2.02 \\
\hline 7 & 2 & 67 & 76 & 1.81 & 1.79 \\
\hline 8 & 4 & 62 & 97 & 2.32 & 2.30 \\
\hline 9 & 4 & 58 & 126 & 2.21 & 2.21 \\
\hline 12 & 4 & 56 & 209 & 1.85 & 1.91 \\
\hline 13 & 4 & 66 & 237 & 1.89 & 1.96 \\
\hline 15 & 2 & 60 & 271 & 2.03 & 2.10 \\
\hline 17 & 2 & 80 & 327 & 2.08 & 2.15 \\
\hline 19 & 2 & 80 & 393 & 2.00 & 2.10 \\
\hline
\end{tabular}

\section{General Observations}

All 108 conductivity values obtained on Leg 19 have been plotted in the histogram shown in Figure 16 and have been used to compute the average thermal conductivity for each site (Table 9). The data appear to fall into two rather indistinct groups. The lower-conductivity group, comprising 86 per cent of the data, includes data obtained in sediment types primarily consisting of nearly pure diatom oozes and diatomaceous silts and clays, with interbedded terrigenous and volcanic sands and silts, as well as volcanic ash layers. There is a distinct tendency for conductivity to increase with clay and, to a lesser extent, silt content. Conductivity values measured in ash, silt, or sand layers are highly variable, perhaps because these sediment types are highly susceptible to mechanical disturbance due to their higher porosity and larger grain size. Thus, both very low (1.75 $\mathrm{mcal} / \mathrm{cm} \mathrm{sec}{ }^{\circ} \mathrm{C}$ at $169 \mathrm{~m}$ in volcanic sand and pumice at Site 184$)$ and very high $\left(3.11 \mathrm{mcal} / \mathrm{cm} \mathrm{sec}{ }^{\circ} \mathrm{C}\right.$ at $298 \mathrm{~m}$ in fine-grained sand at Site 183) values, as well as intermediate values, are characteristic of these sediment types. The high-conductivity group, consisting of fifteen values falling in the range 2.61 to $3.11 \mathrm{mcal} / \mathrm{cm} \mathrm{sec}{ }^{\circ} \mathrm{C}$, are mainly from either coarse-grained turbidite material (Sites 183 and 191), 


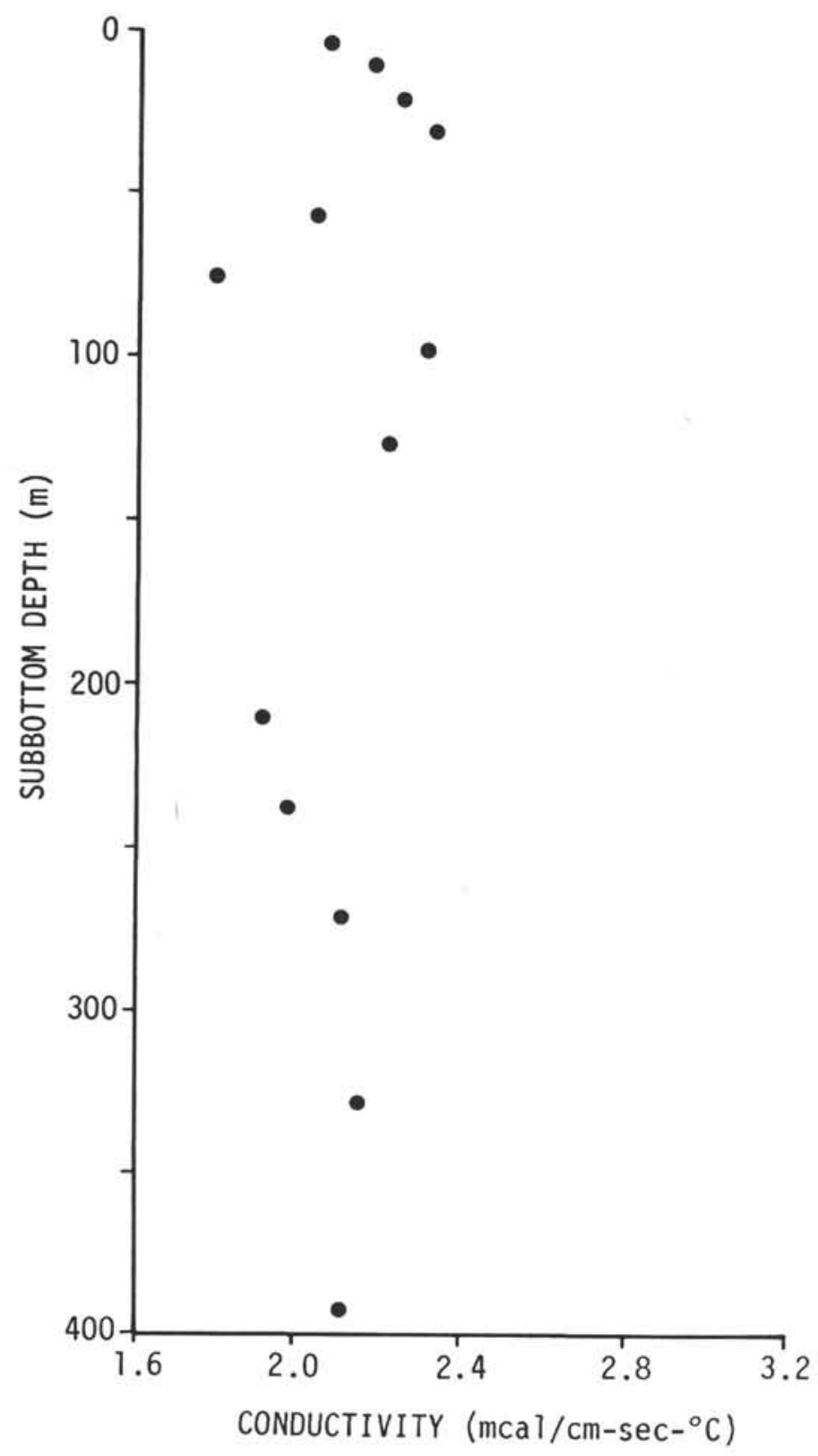

Figure 15. Thermal conductivity versus depth below bottom, Site 192.

highly disturbed, gassy, diatom-bearing clay (Site 185), or diatom-rich or diatom-bearing silty clay (Site 190). If clay content is the determining factor in the thermal conductivity of sediment, the observed bimodal distribution can be interpretted as an indication that the clay content of the sediment increases discontinuously above a certain value corresponding to a thermal conductivity of about 2.5 $\mathrm{mcal} / \mathrm{cm} \mathrm{sec}{ }^{\circ} \mathrm{C}$. It is more likely that the bimodal nature of the histogram is not significant and that additional data could demonstrate the continuity of the thermal conductivity values.

The relation of thermal conductivity to other physical properties is generally weak, possibly because of the highly variable lithology of the sediment on a scale much smaller than the average conductivity measurement interval and the difficulty in assessing the amount of disturbance to the core
TABLE 9

Summary of Leg 19 Thermal Conductivity Data

\begin{tabular}{cccc}
\hline Site & $\begin{array}{c}\text { Number of } \\
\text { Measurements }\end{array}$ & $\begin{array}{c}\text { Mean } \pm \text { Std Dev } \\
\left(\mathrm{mcal}^{\circ} \mathrm{cm} \mathrm{sec}{ }^{\circ} \mathrm{C}\right)\end{array}$ & $\begin{array}{c}\text { Subbottom Depth } \\
\text { Interval }(\mathrm{m})\end{array}$ \\
\hline 183 & 3 & $3.03 \pm 0.10$ & $296-314$ \\
184 & 44 & $2.16 \pm 0.17$ & $132-599$ \\
185 & 20 & $2.04 \pm 0.11$ & $2-227,664-667$ \\
185 & 6 & $2.82 \pm 0.11$ & $670-685$ \\
188 & 7 & $1.88 \pm 0.16$ & $33-285$ \\
190 & 13 & $2.37 \pm 0.33$ & $26-428$ \\
191 & 1 & 3.03 & 18 \\
192 & 13 & $2.10 \pm 0.15$ & $5-393$ \\
193 & 1 & 1.95 & 2 \\
\hline
\end{tabular}

in the immediate vicinity of a conductivity measurement. A few general trends are apparent, however. At Site 184, conductivity tends to correlate directly with density and natural gamma-ray activity (because of the previously discussed relation between clay content and conductivity), inversely with porosity, and not at all with acoustic velocity (Figure 17). The degree of correlation varies markedly both from site to site and with different parameters, as can be seen from Table 10.

These observed relationships suggest that other physical properties can be used to predict conductivity, or vice verse, providing that considerable care is taken to understand and document the proposed relationship. The acquisition and analysis of additional conductivity data will be required to strengthen our understanding of these and other relationships. Reliable conductivity data from homogeneous, undisturbed sections of core are needed to establish these and other relationships.

TABLE 10

Correlation of Thermal Conductivity with Various Parameters

\begin{tabular}{|c|c|c|c|c|}
\hline Site & $\begin{array}{l}\text { Directly with } \\
\text { Bulk Density }\end{array}$ & $\begin{array}{c}\text { Inversely } \\
\text { with } \\
\text { Porosity }\end{array}$ & $\begin{array}{l}\text { With } \\
\text { Acoustic } \\
\text { Velocity }\end{array}$ & $\begin{array}{l}\text { Directly with } \\
\text { Natural Gamma } \\
\text { Activity }\end{array}$ \\
\hline 184 & Good & Good & None & Good \\
\hline 185 & Poor & Poor & None & Good \\
\hline 188 & None & No data & None & Good \\
\hline 190 & None & No data & None & No data \\
\hline 192 & Good & No data & None & No data \\
\hline
\end{tabular}

\section{REFERENCES}

Foster, T. D., 1962. Heat-flow measurements in the northeast Pacific and in the Bering Sea. J. Geophys. Res. 67, 2991.

Langseth, M. G. and Von Herzen, R. P., 1971. Heat flow through the floor of the world oceans. In The Sea, Volume 4. A. Maxwell (Ed.). (Wiley Interscience). Pt. 1, 299.

Ratcliffe, E. H., 1960. The thermal conductivities of ocean sediments. J. Geophys. Res. 65, 1535.

Sverdrup, H. U., Johnson, M., and Fleming, R. H., 1942. The Oceans, their physics, chemistry, and general biology. New York (Prentice-Hall Inc.) 1060 p.

Von Herzen, R. P. and Maxwell, A. E., 1959. The measurements of thermal conductivity of deep-sea sediments by a needle-probe method. J. Geophys. Res., 64, 1557. 


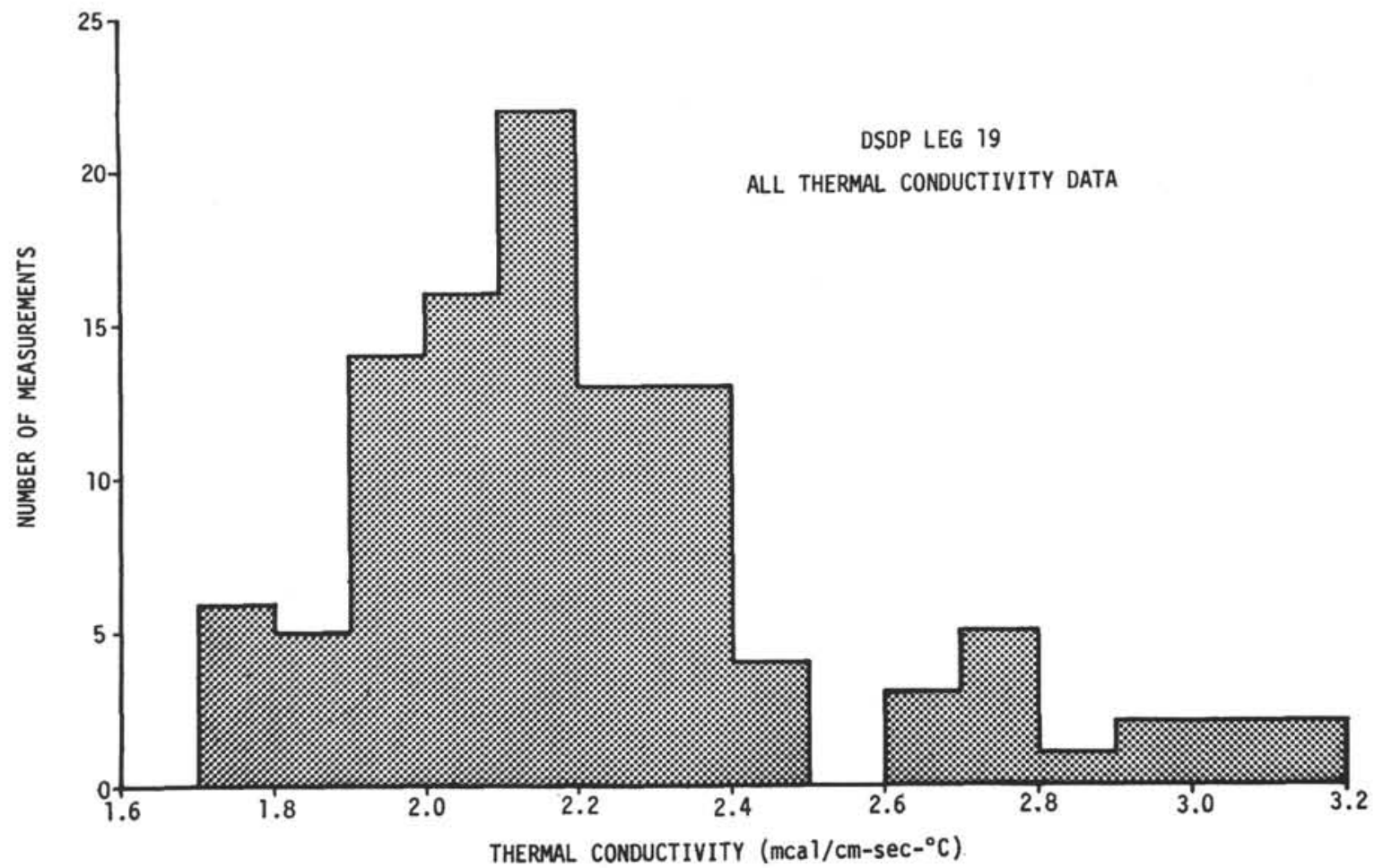

Figure 16. Histogram of thermal conductivity data, Leg 19. 


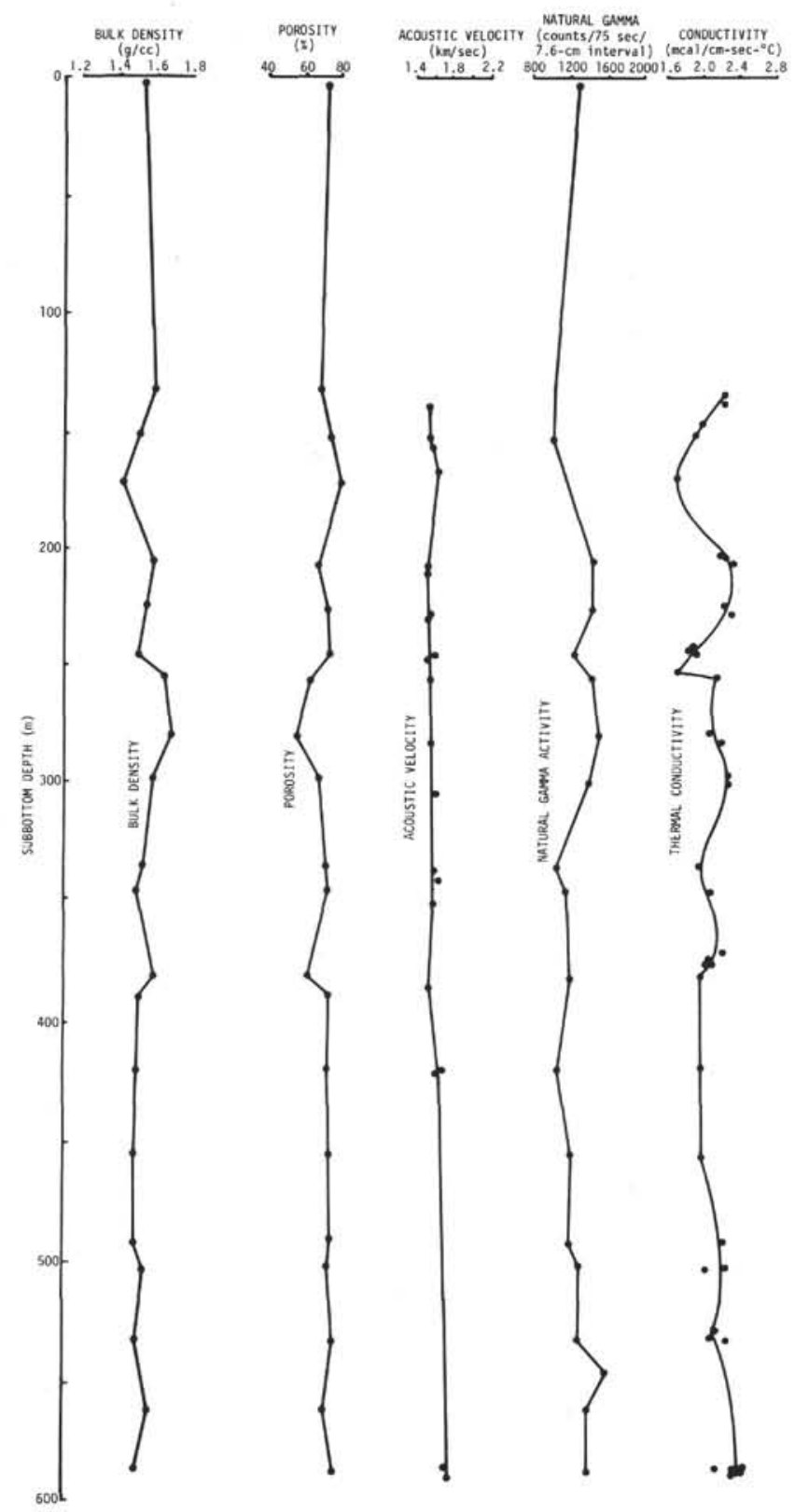

Figure 17. Thermal conductivity and other physical properties versus depth, Site 184. 